\title{
ROLES OF THREE FERRUGINOUS HAWKS AT THE SAME NEST SITE
}

MARTIN BAILEY and CAROL BJORKLUND, 102 - 1833 Coteau Avenue, Weyburn, SK.E-mail: <cmbb@sasktel.net>

The authors observed Ferruginous Hawks at a nest site in a pasture southwest of Weyburn, for 26 hours: from 6:00 a.m. to 6:00 p.m. each day on 23 and 24 May and from 11:00 a.m. to 1:00 p.m. on May 26, 2004. We returned for a final check on June $3^{\text {rd }}$.

May 23rd started as a dreary day. The sky was overcast, with Beaufort four winds (20-29 kph) coming out of the east, temperature $4 \mathrm{C}$ and intermittent drizzle. At 6:00 a.m., a Ferruginous Hawk was sitting on a nest in a tree in a poplar coppice. Soon after, another adult Ferruginous Hawk was seen preening itself on a fence post a half mile to the west of the nest. We spent the next two and a quarter hours following this hawk as it flew from one location within sight of the nest to other locations. Because of size differences and behaviour, it was evident that the larger bird on the nest was the female and the bird flapping from here to there was the male of the pair. ${ }^{1}$ The female on the nest was in high breeding plumage, a huge, brightly coloured bird. The smaller male was less brightly plumed, perhaps due to fading in the sun.

At 8:15 a.m. the winds picked up, gusting to Beaufort five (30-38 kph) with yet more rain. A third Ferruginous Hawk, larger than the male but smaller than the female, was then noticed on a dirt pile within an eighth of a mile of us. It was pale-headed with a lightly streaked back and adult markings on the tail, and when it decided to fly north past the nest site, we noted that its leggings were white - a characteristic of an immature
Ferruginous Hawk and not the rust red of the mature bird. ${ }^{4}$ Each of the three birds was easily distinguished by its distinctive plumage and by size comparison.

The immature landed on a rock pile where it was soon joined by the adult male. There they were sheltered from the rain and the wind. The female remained on the nest. The two birds on the rock pile stayed together from 8:30 to 9:20 a.m., when one of the two flew low to the east and disappeared over the horizon. When we looked back to the rock pile, the other Ferruginous Hawk had also disappeared.

Half an hour later the adult male was seen eating prey on a fence post a mile southwest of the rock pile. The cloud cover had lifted and the sun was making an appearance. The adult male ate its prey in its entirety, then lifted up from the fence post and flew away. It soared and even hovered a mile northwest of the nest. At 11:10 a.m., the male was joined by the immature. They circled about each other once and then broke apart. The adult male flew immediately toward the nest area, presumably carrying prey passed to it in the air by the immature bird. The male was met by the female, who left the nest and flew to meet him on the ground at a point north of the nest site. Within a minute the female was back at the nest; she dropped the prey into the nest and stood on the edge of the nest for about four minutes before settling down onto the nest itself. Presumably, she allowed her chicks to eat the prey by themselves, suggesting that they were large enough to do so, although we did 
not see them. Then the female settled again over the chicks to protect them from rain and wind.

Food was brought to the nest only one more time on 23 May. The female left the nest at 1:23 p.m. and returned by 1:25 p.m. She landed on the ground near the nest copse and quickly brought up an item of prey. It was a Richardson's Ground Squirrel-sized mammal, which she dropped into the nest. She waited on the edge for five minutes before sitting back down. In neither this nor the previous case did she tear up the prey and feed it to the chicks; she merely stood on the edge of the nest and then sat down again.

Both flight hunting and perch hunting, the perch sometimes being the nest site itself, were observed on $23 \mathrm{May}$. These are the two most common hunting methods of the Ferruginous Hawk. ${ }^{3}$

On May 24 the weather had not improved - a steady rain all day. The ceiling was under 500 feet with northwest winds at Beaufort five, and a temperature of $7 \mathrm{C}$. It was hard to see the female on the nest and neither the adult male nor the immature bird was spotted. Twelve hours later, neither the male nor the immature bird had come to the vicinity of the nest site, the female had not eaten all day nor had the chicks been fed. The female had not left the nest for twelve hours, nor even shifted her position on the nest. As we drove away at 6:20 p.m., we saw a Ferruginous Hawk along the road one half mile east of the nest site. It quickly flew south and disappeared.

Returning on 26 May, we saw the immature bird perched on the dirt pile between the nest site and our vehicle. When approached on foot, after an hour and a half of observation from the vehicle, the immature bird flew silently past the nest and over the horizon. The nest appeared empty.
In the evening of 3 June, we returned to the site with Kelly Kozij who climbed up to inspect the large, sturdy stick nest lined with cow manure. One hawk feather was found and nothing else. There was no evidence in the nest or on the ground beneath of remains of young, eggshells or prey. No adults were observed in the vicinity of the nest nor at other alternate Ferruginous Hawk nest sites within three miles.

While Ferruginous Hawk nesting pairs are assumed to be monogamous, sometimes three adults are seen at the same nest, with the possibility of one being a helper (C.S. Houston, pers. comm.). ${ }^{2}$ In this case, there was no competition between the two hawks on the rock pile, and given that there is no evidence that immature Ferruginous Hawks breed, this was not surprising. ${ }^{3}$ As part of the strategy to raise nestlings, helpers have been described amongst a number of bird species. Helpers may be of almost any age, they may be breeding or non-breeding individuals, and they may carry out a variety of activities from feeding the young, to nest defense and attacking enemies venturing too close to community nests. ${ }^{5}$ Three adult birds have been seen on occasion at Ferruginous Hawk nest sites, but no one has speculated on the possible helper role of the third bird (C.S. Houston, pers. comm.). ${ }^{2}$ While it was beyond the capabilities of our telescope to determine whether or not the immature bird handed off prey to the adult male high in the sky, we think it likely. Certainly the adult male flew purposefully in a manner similar to other birds of prey carrying food, and he flew to a spot closer to the nest where he dropped the prey on the ground. It was then retrieved by the female - a typical behaviour pattern that occurs between male and female Ferruginous Hawks.

In conclusion, while it cannot be determined with absolute certainty that the role of the third Ferruginous Hawk at this 
nest site was to help in food gathering for the nestlings, from what was observed on May 23, 2004, it is nevertheless a distinct possibility.

1. GODFREY, W.E. 1986. The Birds of Canada. National Museums of Canada, Ottawa. p. 144

2. JOHNSGARD, P,J. 2001. Prairie Birds. University Press of Kansas, Lawrence. p. 73
3. PALMER, R.S. (ed).1988. Handbook of North America Birds: Volume 5. Yale University Press, New Haven. pp. 141-149

4. SIBLEY, D.A.. 2000. The Sibley Guide to Birds. Alfred A. Knopf, New York. p. 124

5. SKUTCH, A.F. 1976. Parent Birds and Their Young. University of Texas Press, Austin. pp. 351-352

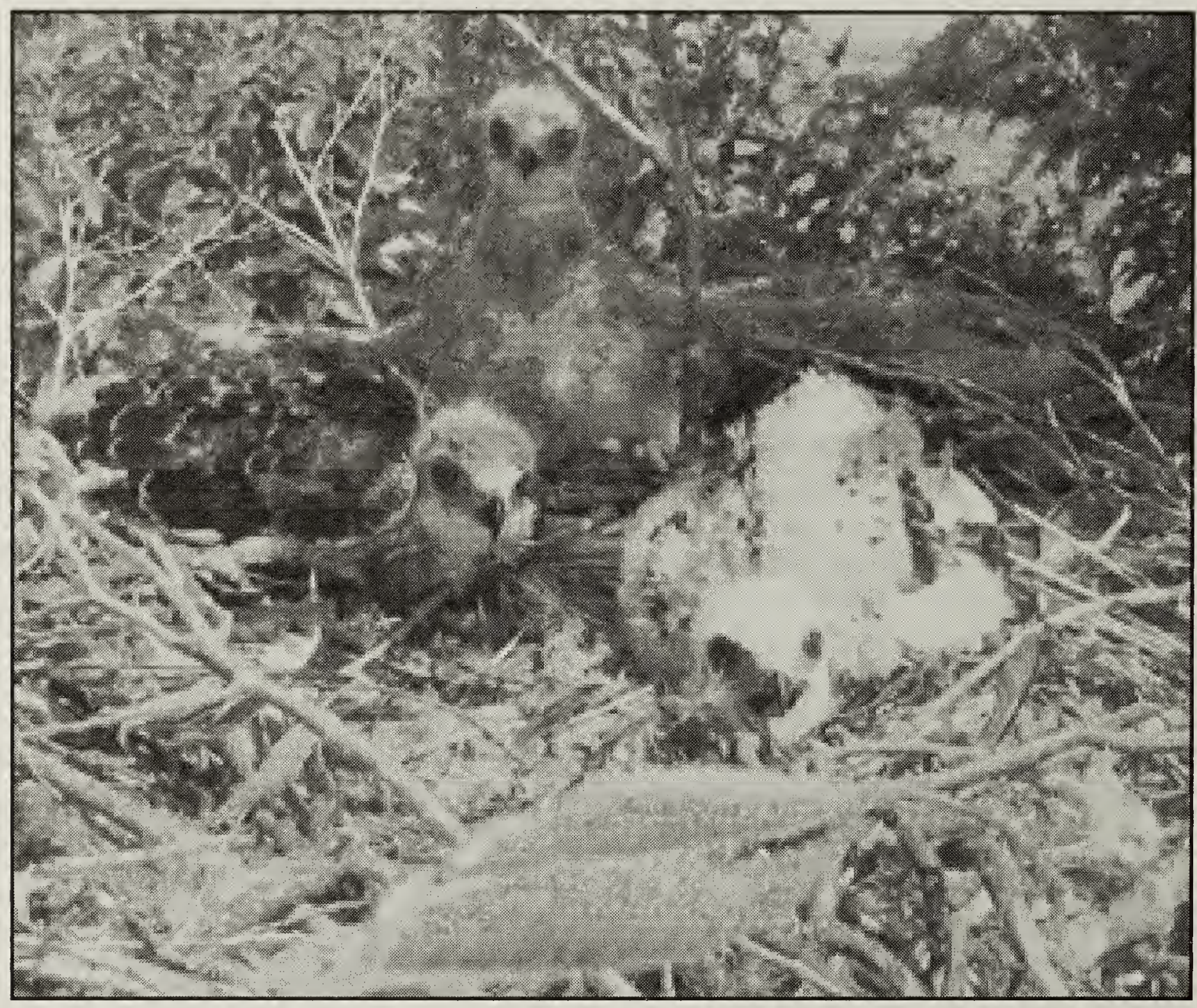

Ferruginous Hawk nestlings

Dan Zazelenchuk

"For some reason the goatsuckers have, for many centuries, been accused of attacking the udders of goats for food. Aristotle wrote that 'flying to the udders of she-goats, it sucked them and so it gets its name. They say that the udder withers when it has sucked at it and that the goat goes blind."'

- Edward S. Gruson, Words for Birds, p 152 